\title{
Role of the seagrass Thalassia testudinum as a source of chromophoric dissolved organic matter in coastal south Florida
}

\author{
Erik R. Stabenau ${ }^{1,2}$, Richard G. Zepp ${ }^{1, *}$, Erich Bartels ${ }^{3}$, Rod G. Zika² \\ ${ }^{1}$ Ecosystems Research Division, National Exposure Research Laboratory, US Environmental Protection Agency, \\ 960 College Station Road, Athens, Georgia 30605, USA \\ ${ }^{2}$ Rosenstiel School of Marine and Atmospheric Sciences, University of Miami, Miami, Florida 33149, USA \\ ${ }^{3}$ Mote Marine Laboratory, Tropical Research Laboratory, Summerland Key, Florida 33042, USA
}

\begin{abstract}
Seagrasses play a variety of important ecological roles in coastal ecosystems. Here we present evidence that seagrass detritus from the widespread species Thalassia testudinum is an important source of ocean color and a UV-protective substance in a low latitude coastal shelf region of the United States. The production and light-induced degradation of chromophoric (sunlightabsorbing) dissolved organic matter (CDOM) from $T$. testudinum was examined under field and controlled laboratory conditions to obtain data that could be used to estimate the contribution of seagrass-derived CDOM to the coastal pool. The laboratory studies measured the temperature dependence and photodegradation of the spectral (UV-visible, fluorescence) and molecular mass properties of CDOM produced during the degradation of $T$. testudinum detritus. The rate of CDOM production is temperature-dependent with rates doubling when temperature increases from 21.4 to $32.6^{\circ} \mathrm{C}$. The magnitude of this increase is close to the widely observed $Q_{10}$ factor for microbial decomposition, indicating that the CDOM production was likely microbially mediated. The absorption coefficients and fluorescence of CDOM from $T$. testudinum decreased on exposure to solar UV radiation (UVR) and the wavelength dependence was determined for this photobleaching process.
\end{abstract}

KEY WORDS: Thalassia testudinum $\cdot$ Seagrass $\cdot$ CDOM production $\cdot$ Coastal ocean color $\cdot$ South Florida $\cdot$ UVR $\cdot$ Photobleaching $\cdot$ Mass spectra

\section{INTRODUCTION}

Seagrasses form extensive meadows throughout the tropical and temperate coastal regions of the earth. They perform a number of important functions in the coastal environment, not least including a significant contribution to the benthic primary production and sediment stabilization (Odum 1971, Duarte 1999, Hemminga \& Duarte 2000). Seagrasses also provide an important substrate for epiphytic algae and sessile invertebrates as well as a significant habitat for mobile fauna, including numerous commercial and recreational fisheries species (Hemminga \& Duarte 2000). The health of seagrass ecosystems is closely linked to the cycling of materials and processes occurring within seagrass meadows and the influence of transported materials from seagrass meadows on other adjacent ecosystems (Odum 1971, Harrison 1989, Ziegler \& Benner 1998, 1999a,b, Hemminga \& Duarte 2000). Although organic matter and nutrient cycling within seagrass meadows has been previously investigated (Harrison 1989, Ziegler \& Benner 1999a,b, Hemminga \& Duarte 2000), comparatively little is known about the possible influence of seagrass-derived organic matter on optical properties of coastal oceans.

Previous studies have indicated that the sunlightabsorbing, i.e. chromophoric, constituent of dissolved organic matter (CDOM) in the coastal ocean contributes significantly to remotely observed color in the coastal ocean and estuaries (Blough \& Green 1994, 
Green \& Blough 1994, Hoge et al. 1995, Coble 1996, Vodacek et al. 1997, Del Castillo et al. 2000, Markager \& Vincent 2000, Moran et al. 2000, Stedmon \& Markager 2001, Twardowski \& Donaghay 2001, Blough \& Del Vecchio 2002, Hu et al. 2002, Zanardi-Lamardo et al. 2002, Zepp 2003a). CDOM is also an important photochemical source of reactive oxygen species in the sea (Kieber et al. 2003) and it is primarily responsible for the attenuation of solar UV radiation (UVR) in coastal environments (Vodacek et al. 1997, Blough \& Del Vecchio 2002, Zepp 2003a). UV exposure has a wide range of potential impacts on coastal ecosystems (Haeder et al. 2003, Zepp 2003a), including inhibition of the photosynthetic activity of corals (Lesser 2000) and of seagrasses (Larkum \& Wood 1993, Detres et al. 2001, Figueroa et al. 2002, Durako et al. 2003).

A few field studies have suggested that seagrasses may be an important source of CDOM in subtropical and tropical coastal ecosystems (Burdige et al. 2002, Zepp et al. 2002). UV protective substances in seagrasses (Detres et al. 2001, Brandt \& Koch 2003, Durako et al. 2003) could provide one source of CDOM to the overlying ocean water. One class of UV-absorbing compounds, the alkanones, is a component of the water-soluble substances released by decomposing seagrass detritus (Hernandez et al. 2001). In this paper, we use the term 'detritus' to refer to senescent blades of seagrass that are frequently found on the ocean bottom and intertidal zones in coastal regions. CDOM is often susceptible to light-induced loss of its UV and visible absorption (Blough \& Del Vecchio 2002, Zepp 2003a), a process referred to as photobleaching. The DOM from the water column of a seagrass meadow (Ziegler \& Benner 2000) as well as the pigments of senescent seagrass (Opsahl \& Benner 1993) photobleached on exposure to natural sunlight. These past studies have provided glimpses of the potential role of seagrasses in CDOM cycling, but no studies have been reported on the dynamics of the production and decomposition of CDOM from living seagrass or seagrass detritus. Identifying the freshwater and marine sources of CDOM and understanding the utilization, degradation and conversion processes responsible for altering their chemical and optical properties is critical to the development of predictive models of this important marine constituent.

The coastal region of Florida Bay through the Florida Keys and out to the reef track is a large transition zone with multiple sources of CDOM. Point source studies have been undertaken in this region to investigate the production of CDOM from the breakdown of terrestrial organic matter (Clark et al. 2002, Zanardi-Lamardo et al. 2002, Stabenau \& Zika 2004). The potential role of seagrass beds as a source of CDOM in this region has not been examined. Seagrass coverage in the south Florida coastal zone has been estimated in excess of $15000 \mathrm{~km}^{2}$ and Thalassia testudinum is a common seagrass in this region (Fourqurean et al. 2001, Peterson \& Fourqurean 2001). In the present study, a combination of field and laboratory studies was used to characterize and quantify the production and decomposition of CDOM derived from $T$. testudinum. The results of these studies were used to assess the contribution of seagrass-derived CDOM to ocean color and UV absorption in the South Florida coastal zone.

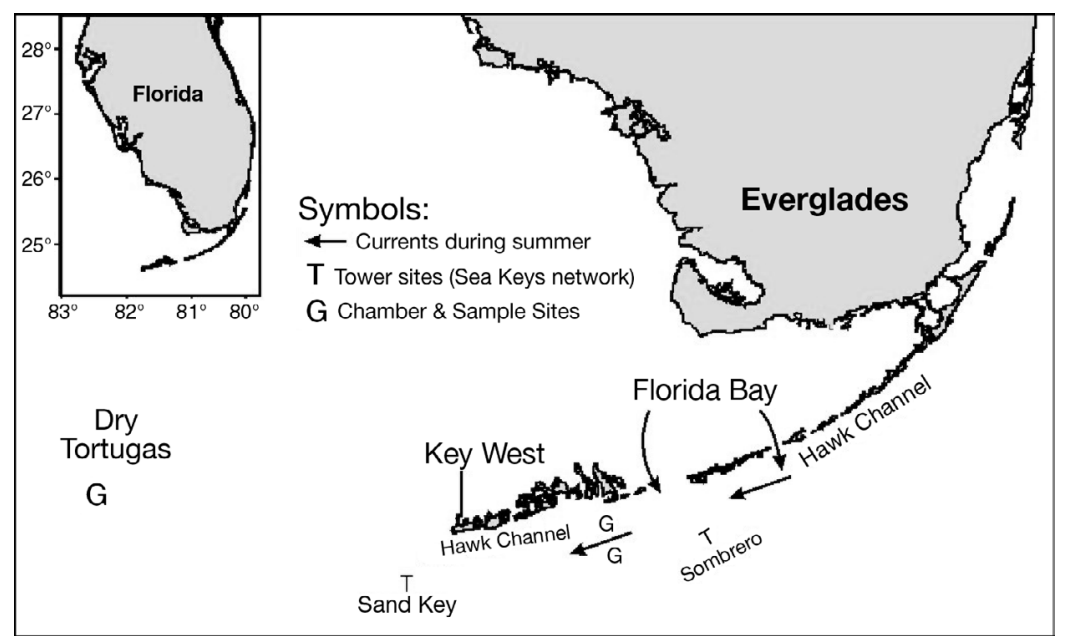

Fig. 1. Study region expanded from box on Florida map. Detail includes arrows to indicate current patterns during summer, major land features of region and the location of seagrass chamber studies and seagrass detritus collection sites (G). T: locations of NOAA Coral Reef Early Warming System (CREWS) network stations where instruments for continuous observations of various oceanic and atmospheric parameters are made

\section{MATERIALS AND METHODS}

Materials. The region investigated in this study included Florida Bay, the Lower Florida Keys and the Dry Tortugas (Fig. 1). Studies of CDOM production were conducted under field conditions and under controlled conditions in the laboratory. The field studies involved collection of water samples over defined time periods from flux chambers located near the Florida Keys reefs. The samples were returned to the laboratory for filtration and optical measurements. The laboratory studies were conducted on seagrass detritus samples under temperature-controlled conditions. Because most of the stations were within an hour of laboratory facilities, time between sample collection and analysis was generally less than 
4 to $5 \mathrm{~h}$. The seagrass detritus used in the laboratory experiments was collected a few hours before the start of the study and kept immersed in aerobic Type I seawater. Water used as a reference standard for the optical measurements and for filter rinsing was treated by a Barnstead Nanopure ${ }^{\circledR}$ Model D-7331 purification system (referred to here as Nanopure ${ }^{\circledR}$ water).

Seagrass CDOM flux experiments. Chamber experiments in situ: The investigation of CDOM derived from Thalassia testudinum was initially performed in situ using sealed Plexiglas chambers that were placed over either seagrass detritus or living seagrass patches in shallow regions north of Looe Key Reef, Florida Keys. For comparison, chambers containing no seagrass biomass were also inserted in the bottom close to the sites used for the grass CDOM flux studies. In all cases, the chamber, which was inserted approximately $3 \mathrm{~cm}$ into the bottom, covered $1 \mathrm{~m}^{2}$ and contained approximately 541 of seawater. The chambers were sampled at $30 \mathrm{~min}$ to $2 \mathrm{~h}$ intervals. During each sampling, water was collected in a pre-cleaned polycarbonate bottle using a specially constructed apparatus. Silicon tubing extending from a 1-way inlet valve attachment sealed through the lid of the bottle was attached to a central exit port of the chamber. The port collected water from 3 inlets inside the chamber. Water flow from the chamber to the bottle was assisted by the attachment of a second 1-way exit valve sealed through the lid of the sample bottle, so that as air was allowed to vent from the sample bottle, water was drawn up from the chamber and into the sample bottle. After sampling, valves on the chamber and sample bottle adaptor cap were closed to prevent leakage of seawater. During 1 experiment, a YSI Model 85 oxygen probe was introduced into a port in the top of the detritus chamber to check oxygen concentrations. The total sample volume per experiment was limited to $3 \%$ of the chamber volume (1.5 1). Water samples were returned to the laboratory, filtered $(<0.2 \mu \mathrm{m}$, polycarbonate filters) and stored at $4^{\circ} \mathrm{C}$ until analysis.

Aquaria experiments - controlled temperature studies. The temperature dependence of CDOM production from Thalassia testudinum detritus was determined by using 6 temperature-controlled continuously mixed aquaria in the laboratory. Type I ocean water (35 l) with very low optical absorption coefficients (e.g. $<0.1 \mathrm{~m}^{-1}$ at $350 \mathrm{~nm}$ ) was added to each of the aquaria, each of which contained an immersion heater and 2 submersible pumps. These systems were allowed to equilibrate to reach a constant temperature overnight prior to introduction of seagrass detritus. Temperatures chosen for the experiment were nominally 22, 28 and $32^{\circ} \mathrm{C}$ with the actual temperature data collected using StowAway TidBit ${ }^{\circledR}$ temperature loggers set to collect 6 samples $\mathrm{h}^{-1}$ (Onset Computer Corp). At the start of the experiment, approximately equivalent samples of T. testudinum were placed in each aquarium by pressing a quantity of seagrass detritus into a $600 \mathrm{ml}$ beaker then transferring the samples into the aquarium. Sampling, which consisted of collecting $100 \mathrm{ml}$ from each aquarium and filtering the sample through $0.2 \mu \mathrm{m}$ polycarbonate filters, began after an initial equilibration time of $1 \mathrm{~h}$. Sampling was conducted as often as every $2 \mathrm{~h}$ for $48 \mathrm{~h}$ with a minimum of 7 discrete samples per experiment. Dissolved oxygen concentrations and salinity were monitored throughout the experiment using a Hydrolab DataSonde 4a multiprobe. Dissolved organic carbon was measured using a Shimadzu TOC Model 5050 carbon analyzer. The total mass of $T$. testudinum in each aquarium was determined by collecting the seagrass after the experiment, rinsing with deionized water and drying until a stable weight was achieved. Conditions for the temperaturecontrolled experiments are shown in Table 1.

Table 1. Rates of chromophoric dissolved organic matter (CDOM) (as measured by increases in absorption coefficients) production from Thalassia testudinum detritus from Looe Key Reef, Lower Keys and from Dry Tortugas. Experiments were conducted under temperature-controlled conditions in aquaria. Spec.: specific

\begin{tabular}{|lccccccc|}
\hline $\begin{array}{l}\text { Temperature } \\
\left({ }^{\circ} \mathrm{C}\right)\end{array}$ & $\begin{array}{c}\text { Detritus } \\
\text { concentration } \\
\left(\mathrm{g} \mathrm{l}^{-1}\right)\end{array}$ & $\begin{array}{c}\text { Rate, } \\
310 \mathrm{~nm} \\
\left(\mathrm{~m}^{-1} \mathrm{~h}^{-1}\right)\end{array}$ & $\begin{array}{c}\text { Spec. rate, } \\
310 \mathrm{~nm} \\
\left(\mathrm{~m}^{-1} \mathrm{~g}^{-1} \mathrm{l} \mathrm{h}^{-1}\right)\end{array}$ & $\begin{array}{c}\text { Rate, } \\
\left(\mathrm{m}^{-1} \mathrm{~h}^{-1}\right)\end{array}$ & $\begin{array}{c}\text { Spec. rate, } \\
360 \mathrm{~nm} \\
\left(\mathrm{~m}^{-1} \mathrm{~g}^{-1} \mathrm{~h} \mathrm{~h}^{-1}\right)\end{array}$ & $\begin{array}{c}\text { Rate, } \\
\left(\mathrm{m}^{-1} \mathrm{n}^{-1}\right)\end{array}$ & $\begin{array}{c}\text { Spec. rate, } \\
412 \mathrm{~nm} \\
\left(\mathrm{~m}^{-1} \mathrm{~g}^{-1} \mathrm{~h}^{-1}\right)\end{array}$ \\
\hline $\begin{array}{l}\text { Looe Key Reef } \\
21.2 \pm 0.3\end{array}$ & 2.44 & 0.0687 & 0.0281 & 0.0428 & 0.0175 & 0.0141 & 0.00577 \\
$21.7 \pm 0.3$ & 3.22 & 0.0903 & 0.0305 & 0.0553 & 0.0172 & 0.0194 & 0.00602 \\
$27.6 \pm 0.1$ & 3.44 & 0.147 & 0.0427 & 0.0850 & 0.0247 & 0.0292 & 0.00848 \\
$27.8 \pm 0.1$ & 2.52 & 0.124 & 0.0493 & 0.0743 & 0.0295 & 0.0268 & 0.0106 \\
$32.4 \pm 0.1$ & 2.43 & 0.142 & 0.0585 & 0.0854 & 0.0352 & 0.0309 & 0.0127 \\
$32.9 \pm 0.1$ & 2.45 & 0.136 & 0.0556 & 0.0819 & 0.0334 & 0.0293 & 0.0120 \\
Dry Tortugas & & & & & & & \\
$28.5 \pm 0.1$ & 2.16 & 0.0884 & 0.0409 & 0.0157 & 0.0246 & 0.0236 & 0.0109 \\
$27.9 \pm 0.2$ & 1.75 & 0.0762 & 0.0435 & 0.0381 & 0.0262 & 0.0205 & 0.0117 \\
$28.2 \pm 0.1$ & 1.44 & 0.0645 & 0.0448 & 0.0098 & 0.0264 & 0.0155 & 0.0108 \\
\hline
\end{tabular}


Optical measurements. Absorption spectra in the UV-visible region from 220 to $1100 \mathrm{~nm}$ were measured using an Agilent Model 8453 Diode Array Spectrophotometer that was equipped with $1 \mathrm{~cm}$ or $10 \mathrm{~cm}$ quartz cells as appropriate. CDOM is typically identified by a broad and featureless exponential decrease in absorption coefficient with increasing wavelength. Nanopure ${ }^{\circledR}$ water was used as the reference. Absorbance measurements were baseline corrected by subtraction of the average absorbance in the 700 to $725 \mathrm{~nm}$ range (Blough \& Del Vecchio 2002). Absorption coefficients $\left(a_{\lambda}\right)$ for the seagrass-derived CDOM were determined using the relationship $a_{\lambda}=2.303 \times\left(D_{\lambda} / L\right)$, where $D_{\lambda}$ is the absorbance at a specific wavelength and $L$ is the cell pathlength. The spectral slope coefficient, $S$, a parameter that quantifies the relationship between the absorption coefficient and wavelength, was calculated for the wavelength range of 280 to $500 \mathrm{~nm}$ using an iterative routine with an exponential non-linear fit equation (Eq. 1) (Blough \& Del Vecchio 2002):

$$
a_{\lambda}=a_{\lambda_{0}} \mathrm{e}^{S\left(\lambda_{0}-\lambda\right)}
$$

High-resolution fluorescence Excitation-Emission Matrix (EEM) scans were performed using an ISASPEX Fluorolog 3-12 scanning fluorometer as described elsewhere (Zepp et al. 2004). Specific regions in the EEM spectra (Coble 1996) were used to differentiate fluorescence from bacterial or aquatic production, terrestrial source CDOM or marine source $\mathrm{CDOM}$. The fluorescence regions utilized for the interpretation of the EEM data in this study are the tryptophan-like or protein-like ' $\mathrm{T}$ ' region at $275 \mathrm{~nm}$ excitation $(\mathrm{ex}) / 310 \mathrm{~nm}$ emission (em), the humic-like ' $\mathrm{A}$ ' region at $260 \mathrm{~nm}$ ex/380-460 $\mathrm{nm}$ em and ' $\mathrm{C}$ ' region at $350 \mathrm{~nm}$ ex/420-480 nm em, and the marine humic-like ' $\mathrm{M}$ ' region at $312 \mathrm{~nm}$ ex/380-420 nm em.

Continuous infusion ion trap mass spectroscopy. The molecular mass distribution from 40 to $2200 \mathrm{Da}$ was determined from analysis of extracts of Thalassia testudinum derived CDOM from both the temperature-controlled aquaria experiments and from the in situ chamber experiments. Samples that had been irradiated for $24 \mathrm{~h}$ as described below were used in the studies of effects of photodegradation on the mass distributions. Details of the extraction and analysis technique are given elsewhere (Stabenau \& Zika 2004).

Photobleaching experiments with Thalassia testudinum-derived CDOM. Photobleaching experiments were performed on water collected at the completion of the temperature controlled Thalassia testudinumderived CDOM production experiments. Filtered water samples were placed in quartz tubes $(1.0 \mathrm{~cm}$ pathlength) with gas-tight septa in crimp-on closures. The tubes were then submerged horizontally in a temperature controlled de-ionized water bath such that the tops of the tubes were within $5 \mathrm{~mm}$ of the water surface. This water bath was then positioned in an Atlas Suntest CPS solar simulator set at $725 \mathrm{~W} \mathrm{~m}^{-2}$ (290 to $800 \mathrm{~nm}$ total irradiance) and irradiated for $24 \mathrm{~h}$. In a series of 3 to $6 \mathrm{~h}$ intervals, samples were removed, analyzed for their UV-visible absorbance and repositioned for further irradiation. At the conclusion of this experiment, samples were also analyzed for variations in spectral slope coefficients and differences in the fluorescence excitation-emission maximum determined by the EEM technique. After spectral analysis, extracts of the irradiated water samples were collected and the molecular mass distribution of the extracts was determined as previously described.

A typical study of the wavelength dependence of photobleaching was conducted by placing a filtered water sample $(50 \mathrm{ml} ; 5.1 \mathrm{~cm}$ pathlength $L)$ in a $3.4 \mathrm{~cm}$ diameter cylindrical cell that was positioned over an upwelling collimated light beam from an Oriel Instruments solar simulator equipped with a $1 \mathrm{~kW}$ xenon arc lamp. The radiation was filtered through a $10 \mathrm{~cm}$ cell filled with Nanopure ${ }^{\circledR}$ water to remove the infrared component and then through glass filters that selectively blocked parts of the UV radiation from the lamp. The spectral irradiance of the filtered radiation was measured using an Optronics Model OL750 spectroradiometer. The UV-visible absorption spectrum and the fluorescence EEM spectrum of the irradiated samples were measured after $30 \mathrm{~min}$ and then at intervals ranging from 1 to $3 \mathrm{~h}$ depending on the rate of photobleaching observed.

\section{RESULTS}

\section{Source and photochemical sinks}

The production of CDOM from the degradation of Thalassia testudinum was measured in aquaria that contained $T$. testudinum detritus that was collected at Looe Key Reef and the Dry Tortugas as well as in Plexiglas chambers placed over seagrass beds near Looe Key Reef. The rate of increase in absorption coefficients, $R(\lambda)\left(\mathrm{m}^{-1} \mathrm{~h}^{-1}\right)$, was directly proportional to seagrass detrital concentration $[S G]$ (g dry wt $\mathrm{l}^{-1}$ seawater) in a series of experiments conducted in aquaria held at $27.6^{\circ} \mathrm{C}$. The slopes of plots of $R(\lambda)$ vs concentration $\left(\mathrm{m}^{-1} \mathrm{~g}^{-1} \mathrm{l} \mathrm{h}^{-1}\right)$ plus statistical data were: $310 \mathrm{~nm}$, $0.046 \pm 0.002\left(\mathrm{r}^{2}=0.985\right) ; 350 \mathrm{~nm}, 0.027 \pm 0.002\left(\mathrm{r}^{2}=\right.$ $0.991)$ and $412 \mathrm{~nm}, 0.0096 \pm 0.0008\left(\mathrm{r}^{2}=0.992\right)$. For analyses of other CDOM production data, the rate for each experiment was converted to a specific production rate $R^{*}(\lambda)\left(\mathrm{m}^{-1} \mathrm{~g}^{-1} 1 \mathrm{~h}^{-1}\right)$ that is defined by Eq. (2):

$$
R^{*}(\lambda)=R(\lambda) /[S G]
$$




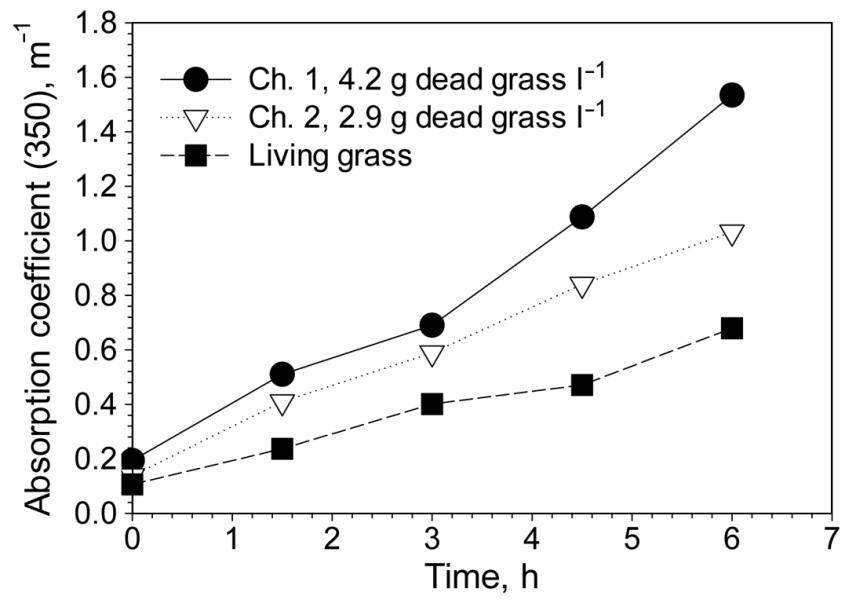

Fig. 2. Time dependence for increase in absorption coefficients at $350 \mathrm{~nm}$ in water samples obtained from Plexiglas chambers (Ch.) that were placed over Thalassia testudinum detritus (dead grass) or over living grass beds underwater near Looe Key Reef, Florida Keys

Experiments were conducted in aquaria maintained at different temperatures and $R^{*}(\lambda)$ values for these experiments are provided in Table 1. These production values were temperature-dependent, increasing with increasing temperature from a mean of $0.0173 \mathrm{~m}^{-1} \mathrm{~g}^{-1} \mathrm{l} \mathrm{h}^{-1}$ at $21.4 \pm 0.2^{\circ} \mathrm{C}$ to $0.0343 \mathrm{~m}^{-1} \mathrm{~g}^{-1} \mathrm{l} \mathrm{h}^{-1}$ at $32.6 \pm 0.2^{\circ} \mathrm{C}$. Specific CDOM production rates at $28^{\circ} \mathrm{C}$ for Thalassia testudinum detritus obtained from the Dry Tortugas were similar to those observed for the CDOM produced from detritus collected in the Lower Keys (Table 1). Other studies were conducted at field sites near Looe Key Reef where Plexiglas chambers were placed over naturally occurring piles of seagrass detritus on the floor of the ocean or over beds of living seagrass. The living seagrass beds contained some seagrass detritus. Absorption coefficients of the water within the chambers increased in an approximately linear fashion over time and the rate of increase was more rapid in the chambers placed over the seagrass detritus (Fig. 2). No detectable change in absorption coefficients occurred in control chambers that were placed over the bare sea floor. Increases in absorption coefficients at $350 \mathrm{~nm}$, normalized to seagrass concentrations, were very similar in the aquaria experiments and the chamber measurements at field sites close to the Looe Key Reef in the Florida Keys (Fig. 3).

Other aquaria experiments were conducted to determine the concurrent time-dependence of the CDOM and dissolved organic carbon (DOC) production. Specific absorption coefficients for CDOM were computed by normalizing the absorption coefficients to the concentration of dissolved

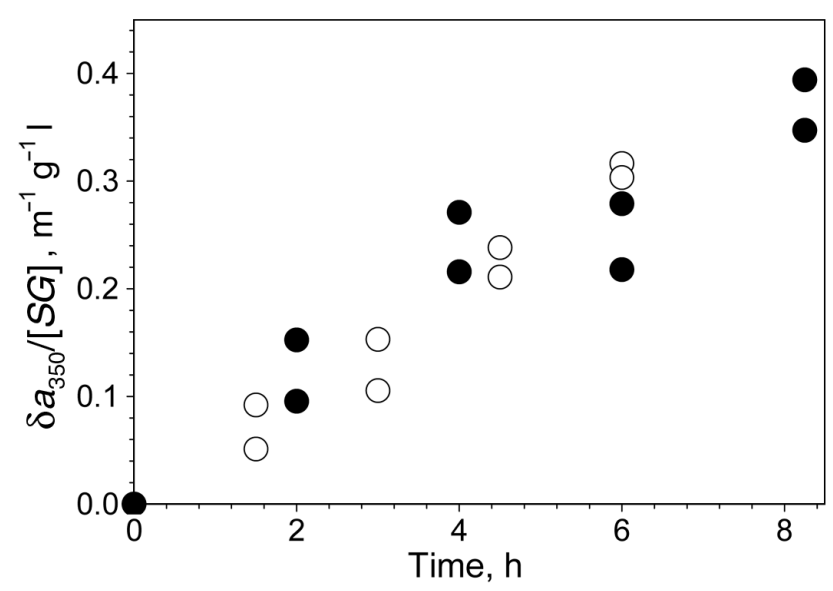

Fig. 3. Comparison of the increase $\left(\delta a_{350}\right)$ in CDOM absorption coefficients of water samples obtained from chambers placed over seagrass detritus near $(O)$ Looe Key Reef $\left(29^{\circ} \mathrm{C}\right)$ and $(0)$ from seagrass detritus in aquaria at $27.7^{\circ} \mathrm{C}$. The absorption coefficients were normalized to the grass concentrations $[S G]$ present in the flux chambers or the aquaria

organic carbon. Typically, the specific absorption coefficients increased throughout the entire time period of the experiments whereas the DOC decreased (Fig. 4).

Initial evaluation of the potential of Thalassia testudinum as a source of CDOM in the coastal environment was through comparison of the UV-visible absorption spectra of seagrass-derived CDOM with previously reported absorption spectra of filtered natural water samples (Blough \& Green 1994, Blough \& Del Vecchio 2002). CDOM produced by T. testudinum has a featureless absorption spectrum that can be described by an exponential function such as Eq. (1). Such

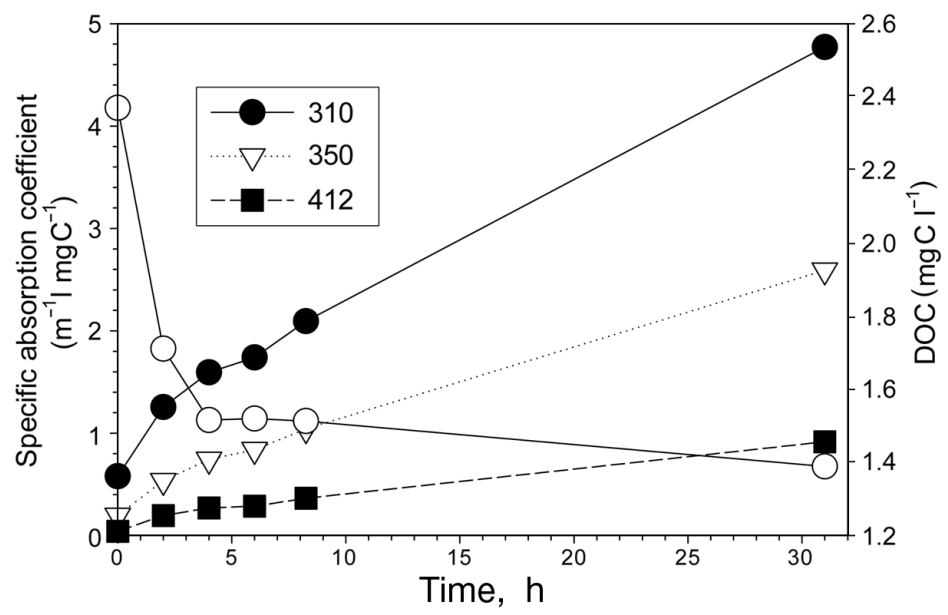

Fig. 4. Changes in specific absorption coefficients for the $\mathrm{CDOM}$ in aquaria experiments conducted at $32.4^{\circ} \mathrm{C}$. Although the DOC $(\mathrm{O})$ decreased over time in the experiments, the CDOM concentration increased 
exponential relationships often describe the absorption spectra of coastal and marine CDOM (Blough \& Green 1994). The spectral slope coefficients for CDOM produced in both the temperature controlled aquaria and the in situ chambers ranged from 0.015 to $0.017 \mathrm{~nm}^{-1}$, regardless of production temperature (Table 1). These values are within the range that was observed for the CDOM in Florida Bay, as well as in the coastal shelf region between land and the reef tract in the Florida Keys known as Hawk Channel (Zepp 2003b). This range is commonly observed for CDOM in coastal ecosystems and freshwaters, but considerably lower than that observed for CDOM in the open ocean. Spectral slope coefficients for open ocean CDOM typically are $>0.025 \mathrm{~nm}^{-1}$ (Blough \& Green 1994, Nelson et al. 1998, Blough \& Del Vecchio 2002). Although the lower coefficients observed in coastal systems are often attributed to CDOM from terrestrial sources, these results show that seagrasses also could be making a significant contribution to the coastal pool of CDOM.

Photobleaching rates were determined for CDOM produced in the controlled temperature experiments under simulated solar radiation with irradiance typical of mid afternoon on a clear July day in the Florida Keys. The samples were irradiated in quartz tubes (1.0 cm pathlength) and immersed in a water bath until absorption coefficients at $350 \mathrm{~nm}$ were reduced to approximately half of their initial value. The photobleaching half-life, $t_{1 / 2}$, at $350 \mathrm{~nm}$ was dependent on the temperature of CDOM production with the shortest being $22.4 \pm 1.7 \mathrm{~h}$ for material produced at $32.6 \pm 0.2^{\circ} \mathrm{C}$ and the longest half-life observed as $35.2 \pm 2.3 \mathrm{~h}$ for material produced at $21.4 \pm 0.2^{\circ} \mathrm{C}$ (Table 2). Inner filter effects (retardation caused by shading resulting from high absorbance) can introduce ambiguities in such comparisons (Hu et al. 2002), but it was shown here that the inner filter effects affected the half-lives by $<5 \%$ in all cases.
Wavelength effects were determined for the photobleaching of the CDOM derived from $20 \mathrm{~h}$ incubation of Thalassia testudinum detritus at $28^{\circ} \mathrm{C}$. The CDOM was exposed to radiation from a xenon arc lamp that was filtered through glass light filters that blocked UV radiation below 290, 320, 335, 345, 360 or $385 \mathrm{~nm}$. As reported for CDOM derived from other sources (Gao \& Zepp 1998, Del Vecchio \& Blough 2002), the UV-visible absorption coefficients of the seagrass-derived CDOM decreased exponentially with increasing irradiation time. A comparison of the rate constants for photobleaching with the various filters in place indicated that the rate constants generally decreased as the cutoff wavelength of the filter increased. With radiation below $385 \mathrm{~nm}$ blocked, the rate constants were reduced by more than $80 \%$ at all wavelengths. In all these experiments, photobleaching was observed where no photons were absorbed by the CDOM, i.e. at wavelengths shorter than the cutoffs of the light filters. The spectral irradiance of the polychromatic light in all 6 experiments with the cutoff filters in place was measured and a wavelength-dependent quantum function, $\mathrm{QF}_{\lambda}$ [units, $\mathrm{m}^{-1}$ (mol photons) ${ }^{-1}$ ] was computed using Eq. (3):

$$
\mathrm{QF}_{\lambda}=(\Delta a)_{\lambda} / E_{\mathrm{abs}, \lambda}
$$

where $(\Delta a)_{\lambda}$ denotes the change observed in absorption coefficient at wavelength $\lambda$ and $E_{\mathrm{abs}, \lambda}$ represents the moles of photons absorbed:

$$
\begin{aligned}
\left(E_{\mathrm{abs}, \lambda}\right)= & \left.E_{\lambda} \text { (mol photons } \mathrm{m}^{-2} \mathrm{~s}^{-1}\right) \times \text { surface area }\left(\mathrm{m}^{2}\right) \\
& \times \text { exposure time }(\mathrm{s}) \times\left(1-\exp a_{\lambda} L\right)
\end{aligned}
$$

where $L$ is the cell pathlength. The quantum function described here differs from apparent quantum yields which are computed from experiments using monochromatic radiation (e.g. see $\mathrm{Hu}$ et al. 2002 and references therein). As others have observed for photobleaching (Whitehead et al. 2000, Osburn et al. 2001,

Table 2. Temperature dependence of photoinduced changes in spectral slope coefficient $(S)$ and photobleaching half-life $(350 \mathrm{~nm})$ of CDOM produced by Thalassia testudinum detritus in aquaria experiments. Table includes spectral slope coefficients of CDOM produced from T. testudinum in chamber experiments conducted near Looe Key Reef at $29.2^{\circ} \mathrm{C}$. The coefficients were computed for the spectral range 290 to $500 \mathrm{~nm}$ using Eq. (1). nd = not determined

\begin{tabular}{|lcccc|}
\hline & $\begin{array}{c}\text { Production } \\
\text { temperature }\left({ }^{\circ} \mathrm{C}\right)\end{array}$ & $S$ & $\begin{array}{c}S \text { after 24 h } \\
\text { photodegradation }\end{array}$ & $\begin{array}{c}\text { Photobleaching } \\
\text { half-life, (h) }(350 \text { nm) }\end{array}$ \\
\hline Aquarium 1 & $21.0 \pm 0.2$ & 0.0169 & 0.0169 & $35.2 \pm 2.3$ \\
Aquarium 2 & $21.2 \pm 0.2$ & 0.0162 & 0.0168 & $25.5 \pm 3.4$ \\
Aquarium 3 & $27.8 \pm 0.2$ & 0.0159 & 0.0170 & $22.4 \pm 1.7$ \\
Aquarium 4 & $27.8 \pm 0.2$ & 0.0161 & 0.0174 & \\
Aquarium 5 & $33.0 \pm 0.2$ & 0.0156 & 0.0172 & nd \\
Aquarium 6 & $33.4 \pm 0.2$ & 0.0158 & nd & nd \\
Chamber 1 - seagrass detritus & 29 & 0.0158 & nd & nd \\
Chamber 2 - seagrass detritus & 29 & 0.0165 & 0.0183 & \\
Chamber 3 - live seagrass bed & 29 & & & \\
\hline
\end{tabular}




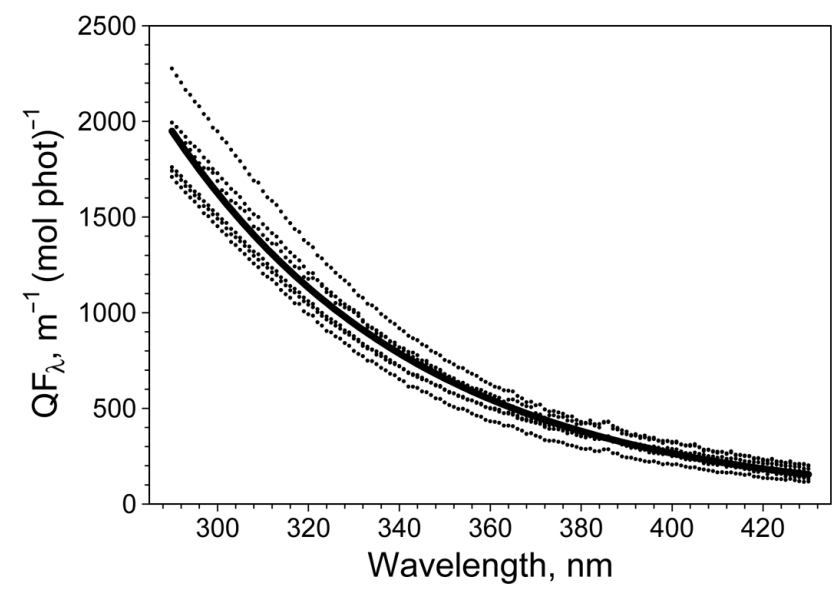

Fig. 5. Quantum function $\left(\mathrm{QF}_{\lambda}\right)$ spectra for photobleaching of CDOM derived from Thalassia testudinum detritus using polychromatic irradiance derived from a xenon arc lamp that was filtered though a Schott WG290 cutoff filter. The quantum function was defined as the ratio of the decrease in the absorption coefficient $\left(\mathrm{m}^{-1}\right)$ to the moles of photons absorbed by the CDOM in the 290 to $430 \mathrm{~nm}$ region (mol photons). Data for experiments with filters that cutoff at 290, 320, 335, 345, 360 and $385 \mathrm{~nm}$ are shown as dots along with a solid line that shows a non-linear exponential fit to all these data. The equation for the fit to all data (290 to $430 \mathrm{~nm})$ is $\mathrm{QF}_{\lambda}=(1949 \pm 11)$ $\exp [-(0.0181 \pm 0.0002)(\lambda-290)]\left(r^{2}=0.964\right)$

Del Vecchio \& Blough 2002, Vähätalo et al. 2002, Osburn \& Morris 2003), the quantum functions decreased exponentially with wavelength and the wavelength dependence over the 290 to $430 \mathrm{~nm}$ range (Fig. 5) could be described by the following expression:

$$
\mathrm{QF}_{\lambda}=\mathrm{a} \exp [-\mathrm{b}(290-\lambda)]
$$

where $\mathrm{a}$ and $\mathrm{b}$ are fitting parameters. The quantum functions for each experiment are compared in Fig. 5. SigmaPlot 8 was used to optimize the fit for each data set and for all data sets to Eq. 5 (Fig. 5). The parameters for the fit of all data were $\mathrm{a}=(1.949 \pm 0.011) \times 10^{3}$ $\left[\mathrm{m}^{-1}(\mathrm{~mol} \text { phot })^{-1}\right]$ and $\mathrm{b}=(1.81 \pm 0.02) \times 10^{-2}\left(\mathrm{~nm}^{-1}\right)$ $\left(r^{2}=0.964\right)$. The fit of all data to a single equation was much poorer if the irradiance from a broader band of wavelengths was used, e.g. 290 to $500 \mathrm{~nm}\left(\mathrm{r}^{2}=0.881\right)$.

Fluorescent properties were determined at the conclusion of both the CDOM production and CDOM photodegradation experiments to determine the principle characteristics of Thalassia testudinum-derived organic material. The EEMs for dark control and irradiated $T$. testudinum-derived CDOM solutions were measured. CDOM from $T$. testudinum has fluorescent properties similar to that observed for the CDOM in Florida Bay water samples and, more generally, for coastal marine CDOM (Sierra et al. 1994, Del Castillo et al. 2000, Moran et al. 2000) with highest fluorescence observed for excitation in the UV. The fluores- cence EEMs of the CDOM from the seagrass detritus exhibited peaks in spectral regions that were observed for the CDOM in water samples from Florida Bay, from Hawk Channel at low tide and from other coastal ecosystems (Sierra et al. 1994, Del Castillo et al. 2000, Moran et al. 2000). In the EEMs of the seagrass CDOM, values above 11 quinine sulfate equivalents (QSE) were observed for the $240 \mathrm{~nm}$ ex/450 nm em peak and 6.5 QSE for the $320 \mathrm{~nm}$ ex/424 $\mathrm{nm}$ em peak. In addition to the marine humic-like (A, $\mathrm{M}$ and $\mathrm{C}$ region) peaks (Coble 1996), there was a fluorescent feature typically indicative of biological production for the peak at $275 \mathrm{~nm}$ em/330 nm ex (T region). The peak in the C and $\mathrm{M}$ region showed a tailing feature toward longer emission wavelengths with longer excitation wavelengths. This feature has been attributed to a mixture of similar fluorophores in previous studies (Sierra et al. 1994, Coble 1996). Variations observed by EEMs due to photobleaching included a reduction in fluorescence for the $\mathrm{C}$ and $\mathrm{M}$ regions as well as an hypsochromic shift (shift to shorter wavelengths). The T peak exhibited no reduction in intensity.

\section{Mass spectra}

Molecular mass distributions were determined for the Thalassia testudinum-derived DOM produced in the temperature-controlled aquaria experiment. Blank correction for these spectra was performed by subtracting the mass distribution for the natural abundance of DOM extracted from the 'blue' water used in the aquaria for the experiments from the mass distribution determined from samples collected at the end of the experiment after $24 \mathrm{~h}$. The molecular mass distribution (Fig. 6a) shows primarily a single broad maximum near 1360 Da and significant mass abundance throughout the 40 to $2200 \mathrm{Da}$ analytical range. For comparison, the inset plot (Fig. 6a) shows the bimodal molecular mass distribution of a coastal DOM sample from the same region. In this bimodal distribution, the higher molecular weight mass region is centered near $1300 \mathrm{Da}$, similar to the location of the seagrass-derived DOM. However, there is an additional lower molecular weight mass distribution that does not appear to be produced in similar abundance during the degradation of $T$. testudinum.

Photodegradation experiments were performed on samples produced at each of the 3 temperature regimes in order to determine if the molecular mass distribution is affected by exposure to sunlight and if so, to identify markers of this change that could be used to determine the degree of photodegradation in natural samples. Sub-samples from the photobleaching experiment were extracted and analyzed by continuous flowing ion 
trap mass spectrometry to determine their molecular mass distributions. The change in molecular mass distribution, in positive and negative modes, was similar for all Thalassia testudinum samples. An example of this change is provided in Fig. 6b. In this plot, the $x$-axis shows the molecular mass observed while the $y$-axis shows the change in abundance that occurred during photodegradation. A loss of abundance is visible as a negative value while an increase in abundance is shown as a positive value. A continuous region of reduced abundance was observed in the photodegraded CDOM for every mass between 700 and 2000 Da in both positive and negative mode. The photodegradation was quantified for each compound mass in the 700 to 2000 Da region as a percent of abundance in the unirradiated sample. As in the case of the photobleaching results discussed earlier, the photoinduced changes in the spectra

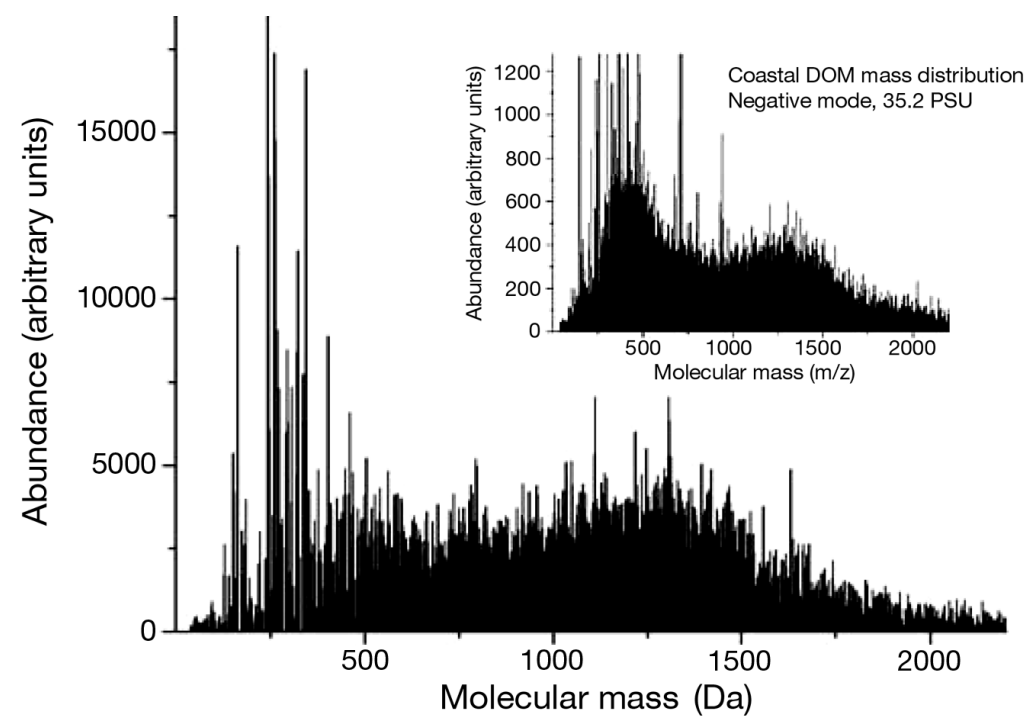

a for the 700 to 2000 Da region were dependent on the temperature of CDOM production. For the positive mode ionization data, the highest loss after $24 \mathrm{~h}$ of irradiation in the solar simulator, $65 \pm 46 \%$, was observed for the samples produced at $32^{\circ} \mathrm{C}$ followed by $49 \pm 49 \%$ and $30 \pm 29 \%$ for samples produced at 28 and $22^{\circ} \mathrm{C}$ respectively. These percentage losses were close to those observed for decreases in absorption coefficients of the samples at $350 \mathrm{~nm}$ after $24 \mathrm{~h}$ of irradiation, suggesting that photodegradation of compounds with masses in the 700 to 2000 Da region made a large contribution to photobleaching of the CDOM. High variation in these values was due to the inclusion of a few compounds that did not show appreciable loss during photodegradation. The spectra of the photodegraded CDOM below 700 Da exhibited a mixed pattern of increasing and decreasing abundance that was inconclusive.

\section{DISCUSSION}

In shallow coastal shelf regions such as Florida Bay and Hawk Channel, large amounts of biomass are produced by submerged aquatic vegetation. Around the Florida Keys and other global locations where coral reefs are located, seagrasses are a major producer of decomposing organic matter. Thalassia testudinum (Peterson \& Fourqurean 2001) is a particularly significant component of the biomass in the coastal shelf region of the Florida Keys and Florida Bay. Results of this study indicate that aerobic decomposition of $T$. testudinum produces CDOM that has optical and
Fig. 6. (a) Mass distribution of dissolved organic matter derived from the degradation of Thalassia testudinum detritus as determined by continuous infusion electrospray ionization ion trap mass spectroscopy in negative ionization mode. The inset illustrates mass distribution from coastal DOM sample comparison. (b) Photodegradation-induced changes in molecular mass abundance in negative ionization mode for $\mathrm{CDOM}$ produced at $22^{\circ} \mathrm{C}$ after the sample was exposed to simulated solar radiation for $24 \mathrm{~h}$. pos.: positive 
mass spectral properties that are very similar to those observed for CDOM in coastal shelf waters of Florida Bay and the Florida Keys. Additionally, the production rate of CDOM from seagrass detritus was determined to be temperature dependent.

\section{Seagrass as a source of $\mathrm{CDOM}$}

Two major sources of CDOM in coastal areas are widely recognized: CDOM that is terrestrially derived and microbially derived (Zepp 2003a). Terrestrially derived CDOM originates through the decomposition of nonliving plant material and it is introduced into water via leaching and runoff from land. CDOM can also be produced through the decay of phytoplankton detritus; this source of CDOM has been referred to as 'microbially derived' (McKnight et al. 2000). Seagrasses are well known as a major source of biomass in the coastal ocean (Odum 1971, Harrison 1989, Hemminga \& Duarte 2000) and have been investigated for their role in the production of bioavailable DOC (Ziegler \& Benner 1999a, 2000). Ziegler et al. (2000) mentioned that compounds in the water of a subtropical seagrass meadow absorbed UV radiation and that exposure to solar radiation resulted in photobleaching of water samples from this system. Both Burdige et al. (2002) and Zepp et al. (2002) mentioned in oral presentations that seagrasses may be an important source of CDOM in oligotrophic ocean water of the Bahamas or around the Florida Keys, respectively. The relative contribution of seagrass to the coastal CDOM pool and subsequent influence on ecosystem optical properties has not been investigated.

Chamber studies conducted over nonliving or living seagrass near the Looe Key Reef in the Lower Keys indicated that decomposing seagrass detritus was a more potent source of CDOM than living seagrass (Fig. 2). These studies were conducted under aerobic conditions. No flux of CDOM from the bare sand bottom was observed. However, other recent studies by Burdige et al. (2004) have shown that anaerobic zones of bottom sediments may be an important source of CDOM. Although not included in this investigation, such fluxes from anaerobic sediments could be a significant source of CDOM in coastal regions of South Florida such as Florida Bay.

Studies then conducted under controlled conditions in the laboratory established that the production rate of CDOM was approximately proportional to the concentration of the seagrass detritus in the water expressed as $g$ dry weight (wt) $\mathrm{l}^{-1}$. Therefore, to generalize our findings, the CDOM production rates that we observed in the aquaria and in the chambers on the ocean floor were normalized to the seagrass concentration (g dry wt $\mathrm{l}^{-1}$ ) in the system investigated. Because the absorption coefficients of seagrass-derived CDOM decrease exponentially with increasing wavelength, as CDOM was produced by the decomposition of the seagrass detritus, the rate of increase in absorption coefficients increased with decreasing wavelength. The production rates increased with increasing temperature (Table 1), approximately doubling with a $10^{\circ} \mathrm{C}$ increase. The magnitude of this increase is close to the widely observed $Q_{10}$ factor for microbial decomposition, indicating that the CDOM release to the seawater likely was microbially mediated. Production rates, taking temperature into account, were the same in the aquaria and in the flux chamber experiments conducted in the field (Fig. 3). Specific absorption coefficients (absorption coefficient normalized to DOC) for the CDOM and DOC in the aquaria were dynamic during the aquaria experiments (Fig. 4). The DOC actually decreased throughout the experiments but the specific absorption coefficients increased. These results likely indicate that a large fraction of the DOC initially produced by the seagrass detritus was non-absorbing organic matter that was readily degraded by microorganisms in the system. These results suggest that the high bacterial activity previously observed in a subtropical seagrass meadow (Ziegler \& Benner 1999a, 2000) is in part attributable to bioavailable organic compounds produced by the decomposing seagrass detritus. Clearly, exudation of labile DOM by the living seagrass exposed to sunlight makes a major contribution as well (Ziegler \& Benner 1999a, 2000).

Spectral slope coefficients discussed earlier in the paper provide an important criterion for judging the source of CDOM. The spectral slope coefficients for seagrass-derived CDOM in the UV and short-wavelength spectral region (290 to $500 \mathrm{~nm}$ ) were approximately independent of the temperature in the aquaria and were similar to spectral slope coefficients that are observed in Florida Bay (Green \& Blough 1994, Zepp 2003b), in Hawk Channel at low tide (Zepp 2003b) and in many coastal waters (Blough \& Green 1994, Blough \& Del Vecchio 2002). The CDOM in the open ocean has much different absorption spectra with $S$ values often in excess of $0.025 \mathrm{~nm}^{-1}$ (Nelson et al. 1998, Blough \& Del Vecchio 2002, Zepp 2003b).

\section{Photobleaching of seagrass-derived CDOM}

Past studies have indicated that the polymeric substances that make up CDOM are not readily decomposed by microorganisms, but CDOM bioavailability changes on exposure to solar radiation (Mopper \& Kieber 2000, Moran et al. 2000, Ziegler \& Benner 2000, Blough \& Del Vecchio 2002, Miller et al. 2002, Zepp 
2003a). It has been known for years that absorption of solar UV radiation by terrestrially derived humic substances and CDOM results in a reduction in its light absorption and fluorescence (i.e. photobleaching) (Moran \& Zepp 1997, Miller 1998, Mopper \& Kieber 2000, Whitehead et al. 2000, Del Vecchio \& Blough 2002, Zepp 2003a). The present studies confirm that the CDOM derived from seagrass detritus also photobleaches and that the photobleaching process is accompanied by increases in the spectral slope coefficient.

The photoproduction of biologically labile photoproducts often, but not always, accompanies photobleaching (Blough \& Del Vecchio 2002, Del Vecchio \& Blough 2002, Zepp et al. 2003a). The study of a seagrass Thalassia testudinum meadow by Ziegler et al. (2000) indicated that photoreaction of the CDOM in the water column produced little detectable bioavailable compounds. Ziegler et al. (2000) used the microbial uptake of tritiated leucine as their technique for measuring bioavailable photoproducts. In contrast, another recent study using a more sensitive technique involving microbial $\mathrm{CO}_{2}$ production (Moran et al. 2000, Miller et al. 2002) indicated that the photodecomposition of CDOM produced by $T$. testudinum does produce bioavailable photoproducts (Zepp et al. 2003b). The difference in these results may reflect differences in the sensitivity of these 2 methods. Also, as noted by Ziegler et al. (2000), competing uptake of tritiated leucine by phytoplankton could have resulted in underestimates of the production of bioavailable photoproducts by the bacteria.

Our studies indicated that seagrass-derived CDOM is readily photobleached by solar radiation (Table 2). The decrease in absorption coefficients in the UV spectral region with increasing exposure time was exponential and first-order kinetic expressions were used to describe the photobleaching kinetics. Half-lives for the photobleaching at $350 \mathrm{~nm}$ were dependent on the production temperature of the CDOM. The half-lives decreased with increasing production temperature. Photobleaching of the CDOM resulted in increases in the spectral slope coefficients (Table 2). The photobleaching half-lives $\left(t_{1 / 2}=22.4 \pm 1.7\right.$ to $\left.35.2 \pm 2.3 \mathrm{~h}\right)$ were similar to those observed for terrestrially derived CDOM from a coastal estuary in the southeastern United States irradiated under similar conditions $\left(t_{1 / 2} \approx\right.$ $32 \mathrm{~h}$, Moran et al. 2000).

Changes in the fluorescence spectra of the seagrassderived CDOM were also observed on exposure to solar radiation. As has been observed with terrestrially derived CDOM (Coble 1996, Del Castillo et al. 2000, Moran et al. 2000, Del Vecchio \& Blough 2002), the fluorescence intensity in the humic region of the EEMs decreased to a greater extent than the absorption coefficient at $350 \mathrm{~nm}$. Concurrent with this reduction in fluorescence efficiency, emission maxima underwent hypsochromic shifts (shifts to shorter wavelengths).

Previous studies have indicated that apparent quantum yields for production of trace gases and reactive oxygen species by CDOM generally decrease with increasing wavelength in the UV and visible spectral region (Blough \& Del Vecchio 2002, Kieber et al. 2003, Zepp 2003a). The apparent quantum yields were typically determined using monochromatic radiation. Wavelength effects on photobleaching have shown that loss in absorbance at a particular wavelength is caused not only by light absorption at that wavelength but also by light absorbed at longer wavelengths (Whitehead et al. 2000, Del Vecchio \& Blough 2002, Vähätalo et al. 2002, Osburn \& Morris 2003, Vähätalo \& Wetzel 2004). In this study, loss of absorbance in the short-wavelength UV-B (280 to $315 \mathrm{~nm}$ ) region was observed, albeit at a reduced rate, even when the CDOM was irradiated with radiation of wavelengths $>385 \mathrm{~nm}$. Because interactions over a wide range of wavelengths can induce photobleaching at a particular wavelength, we chose to quantify our results by ratioing the absorption coefficient changes to light quanta absorbed by the CDOM over a broad wavelength range (Eq. 3). This ratio is referred to here as the photobleaching 'quantum function.' Whitehead et al. (2000) used a similar approach in their analyses of polychromatic photobleaching of the CDOM from the St. Lawrence Estuary. Photobleaching quantum functions for the seagrass-derived CDOM decrease with increasing wavelength (Fig. 5), an effect that has been observed with terrestrially derived CDOM (Whitehead et al. 2000, Osburn et al. 2001, Vähätalo et al. 2002, Osburn \& Morris 2003, Vähätalo \& Wetzel 2004). The wavelength dependence for photobleaching of the seagrass CDOM was similar to that reported by Whitehead et al. (2000).

\section{Mass spectra of seagrass-derived CDOM}

In previous work, the mean of the higher molecular weight mass distribution in CDOM extracts from coastal water samples has been shown to correlate with changes in absorbance and fluorescence intensity (Clark et al. 2002, Zanardi-Lamardo et al. 2002, Stabenau \& Zika 2004). The current study indicates that this same mass region, between 700 and 2000 Da with a mean between 1300 and $1400 \mathrm{Da}$, is produced during the degradation of Thalassia testudinum. This result suggests that at least a subset of the compounds observed in this mass range in natural samples may be from this source. A reduction in abundance in this molecular weight fraction occurs during irradiation of the T. testudinum-derived CDOM with sunlight. The com- 
bined effect of this loss of high molecular weight compounds and the increasing abundance of select lower molecular weight compounds produces an apparent reduction in mean mass, as previously observed for CDOM during aging and sunlight exposure (Grzybowski 2000, Zanardi-Lamardo et al. 2002, Stabenau \& Zika 2004). In previous work, the high molecular weight region was attributed to relatively new DOM, produced during the degradation of terrestrial organic matter. In the current study, T. testudinum is identified as an additional source of high molecular weight chromophoric dissolved organic matter, further complicating the task of understanding CDOM in transitions zones.

\section{Estimating seagrass-derived CDOM concentrations in a coastal ecosystem}

The contribution of CDOM derived from Thalassia testudinum to absorption coefficients observed in Florida Bay was estimated by comparing modeled and observed CDOM absorption coefficients for this region. The concentration of CDOM that could be produced from this source was determined by considering production and photobleaching rates observed in the laboratory studies. The following stepwise procedure was used for the estimate:

(1) The total living biomass of Thalassia testudinum within the bay $\left(M_{\text {liv }}\right)$ is estimated to be between $6.4 \times 10^{7} \mathrm{~kg}$ and $1.4 \times 10^{8} \mathrm{~kg}$ (Zieman et al. 1989, Fourqurean et al. 2001). The growth and death are approximately balanced at a rate constant of $\left(k_{\mathrm{d}}\right)$ of $0.18 \mathrm{yr}^{-1}$ (Peterson \& Fourqurean 2001). The biological decay rate $\left(k_{\text {dec }}\right)$ of the seagrass detritus is $0.20 \mathrm{yr}^{-1}$ (Rice \& Tenore 1981). Assuming steady state conditions in which the death rate equals the decay rate of the detritus, i.e. $k_{\mathrm{d}} \times M_{\text {liv }}=k_{\mathrm{dec}} \times M_{\text {det }}$, the lower limit on the mass of seagrass detritus $\left(M_{\text {det }}\right)$ is approximately $6.5 \times 10^{10} \mathrm{~g}$.

(2) The total volume of the bay of is $3.24 \mathrm{~km}^{3}$ or $3.24 \times 10^{12} l$, based on an average depth of $1.8 \mathrm{~m}$ and an area of $1800 \mathrm{~km}^{2}$. Therefore, the lower limit for the concentration of seagrass detritus is about $2.0 \times 10^{-2} \mathrm{~g} \mathrm{l}^{-1}$.

(3) Assuming a mid-summer CDOM production rate of $0.030 \mathrm{~m}^{-1} \mathrm{~g}^{-1} \mathrm{l} \mathrm{h}^{-1}$ at $350 \mathrm{~nm}$ (Table 1 assuming water temperature is $30^{\circ} \mathrm{C}$ ), we estimate that total CDOM production is $6.0 \times 10^{-4} \mathrm{~m}^{-1} \mathrm{~h}^{-1}$ or $1.4 \times 10^{-2} \mathrm{~m}^{-1} \mathrm{~d}^{-1}$.

(4) The near surface, clear sky photobleaching rate constant for the CDOM at $350 \mathrm{~nm}$ (Table 2) is about $0.3 \mathrm{~d}^{-1}$ in summer. Taking light attenuation by clouds (about $30 \%$ reduction from clear sky irradiance) (Frederick \& Lubin 1988) and scattering and absorption in the water column into account (60 to $70 \%$ reduction in average photobleaching rate due to light attenuation in the water column of $1.8 \mathrm{~m}$ ) (Stumpf et al. 1999), we estimate that the photobleaching rate constant $\left(k_{\text {phot }}\right)$ in summer is about 0.063 to $0.084 \mathrm{~d}^{-1}$.

(5) If photobleaching were the only pathway for loss of the seagrass-derived CDOM in Florida Bay, then at steady state, the production rate of the CDOM $\left(1.4 \times 10^{-2} \mathrm{~m}^{-1} \mathrm{~d}^{-1}\right)$ equals the photobleaching rate $\left(k_{\text {phot }} \times a_{350}\right)$ and the computed absorption coefficient due to seagrass detritus-derived CDOM is in the 0.17 to $0.22 \mathrm{~m}^{-1}$ range. In comparison, the mean value for absorption coefficients at $350 \mathrm{~nm}$ observed during June on a transect from Seven Mile Bridge through several stations maintained by Florida International University in Florida Bay (FIU392, FIU393 and FIU394) was $0.41 \pm 0.03 \mathrm{~m}^{-1}$. This comparison suggests that a substantial part (up to $40-50 \%$ ) of the CDOM in this region may be seagrass-derived. Other physicochemical processes such as flocculation and sedimentation can potentially remove CDOM from Florida Bay as well. However, Del Castillo et al. (2000) have presented evidence that flocculation and sedimentation do not have a major influence on removal of CDOM over the West Florida Shelf.

Other sources such as the mangroves and decaying plant litter in the Everglades are also likely contributing to the CDOM in this area. The possible role of mangrove forests as a source of CDOM in subtropical coastal regions, including those of South Florida, has been noted elsewhere (Zepp et al. 2002, Zepp 2003b, Jaffé et al. 2004). Based on this analysis, plus the similarities in mass spectral and fluorescence spectra of the CDOM in Florida Keys waters and that of the seagrassderived CDOM, we conclude that seagrass is a significant source of CDOM in Florida Bay and around the coral reefs in the Florida Keys.

\section{Seagrass-derived CDOM and UV exposure in the Florida Keys}

Another study by Zepp et al. (2003b) has shown that CDOM controls the penetration of UV-B radiation into waters over the coral reefs in the Florida Keys. If the seagrass contributes close to one-half of the diffuse attenuation coefficients for UV-B radiation over the reefs, then complete loss of the seagrass input could substantially increase UV-B exposure of the reefs. For example, typical diffuse attenuation coefficients at $305 \mathrm{~nm}$ over the Looe Key Reef are in the 0.3 to $0.5 \mathrm{~m}^{-1}$ range (Zepp 2003b). It can be shown that, at corals depth of $4.0 \mathrm{~m}$, a factor of 2 reduction in diffuse attenuation coefficients caused by loss of seagrass-derived CDOM translates to an 82 to $170 \%$ increase in exposure to $305 \mathrm{~nm}$ radiation (Zepp 2003b). 


\section{CONCLUSIONS}

This investigation indicates that the widespread seagrass Thalassia testudinum can be a significant CDOM source in low latitude coastal shelf regions of the United States that has not been previously identified. The dissolved organic matter released by degrading seagrass detritus has specific absorption coefficients, spectral slope coefficients, fluorescence EEM features and molecular mass distribution that are similar to those observed for CDOM attributed to terrestrial sources. The rate of CDOM production observed in this investigation was temperature-dependent with rates increasing from $0.029 \pm 0.01 \mathrm{~m}^{-1} \mathrm{~g}^{-1} \mathrm{l} \mathrm{h}^{-1}$ at $21.4 \pm 0.2^{\circ} \mathrm{C}$ to $0.057 \pm 0.01 \mathrm{~m}^{-1} \mathrm{~g}^{-1} \mathrm{~h}^{-1}$ at $32.6 \pm 0.2^{\circ} \mathrm{C}$. The absorption coefficients and fluorescence of CDOM from $T$. testudinum decrease on exposure to solar radiation and UV, and short-wavelength visible components of solar radiation are mainly responsible for this 'photobleaching' process. By considering the production and photobleaching rates and the biomass and turnover rate, $T$. testudinum was shown to be a potentially significant source of CDOM in Florida Bay.

Comparisons of the optical (similar spectral slope coefficients, increasing spectral slope coefficients on photobleaching) and mass spectral properties (similar mean mass of upper mass distribution, apparent reduction of mean mass on photobleaching) of seagrassderived CDOM and CDOM in waters over the coral reefs in the Florida Keys indicate that seagrasses could be an important source of UV-protective compounds in the water. Therefore, decreases in seagrass beds due to shifts in temperature, salinity, increased frequency of disease, changes in predation and other factors may contribute to increases in UV exposure of organisms such as coral assemblages that live in close proximity to the seagrasses. However, quantitative estimates of the effects of climate change on seagrass-derived CDOM are complex. For example, the rate of CDOM production from seagrass detritus increases with water temperature, but the rate of CDOM photobleaching also increases with increasing production temperature. The net effect of these 2 competing processes, the increased production expected at higher temperatures and increased photobleaching of those compounds, is not clear from the current data. Moreover, changes in precipitation patterns and human activities such as the regulation of release rates of waters from the Everglades can also strongly influence inputs of terrestrially derived materials, both chromophoric and nutrients that can directly or indirectly affect UV penetration into the coastal shelf region. Additional research on CDOM sources and sinks are required to evaluate how future regional changes in climate and human activities will affect ocean color and related factors such as underwater UV exposure in subtropical coastal regions.

Acknowledgements. We thank P. Carlson for use of his Plexiglas flux chambers for the CDOM grass flux studies. We also thank S. Anderson and E. Mueller for their assistance and advice. This research was supported in part by a grant from US EPA agreement no. 98-NCERQA-R and a grant from the Office of Naval Research to R.G.Z. (N00014-98-F-0202). E.R.S. was a US EPA NNEMS fellow. This paper has been reviewed in accordance with the US Environmental Protection Agency's peer and administrative review policies and approved for publication. Mention of trade names or commercial products does not constitute an endorsement or recommendation for use by the US EPA.

\section{LITERATURE CITED}

Blough NV, Del Vecchio R (2002) Distribution and dynamics of chromophoric dissolved organic mater (CDOM) in the coastal environment. In: Carlson C (ed) Biogeochemistry of marine dissolved organic matter. Academic Press, Ann Arbor, MI

Blough NV, Green SA (1994) Spectroscopic characterization and remote sensing of non-living organic matter. In: Sonntag C (ed) Role of non-living organic matter in the earth's carbon cycle. Wiley, New York, p 42-57

Brandt LA, Koch EW (2003) Periphyton as a UV-B filter on seagrass leaves: a result of different transmittance in the UV-B and PAR ranges. Aquat Bot 76:317-327

Burdige DJ, Boss E, Zaneveld R (2002) The role of seagrasses as a source of CDOM to tropical coastal waters. EOS Trans AGU 83:OS32R-01, American Geophysical Union, Washington, DC

Burdige DJ, Kline SW, Chen W (2004) Fluorescent dissolved organic matter in marine sediment pore waters. Mar Chem 89:289-311

Clark CD, Jimenez-Morais J, Jones G, Zanardi-Lamardo E, Moore CA, Zika RG (2002) A time-resolved fluorescence study of dissolved organic matter in a riverine to marine transition zone. Mar Chem 78:121-135

Coble PG (1996) Characterization of marine and terrestrial DOM in seawater using excitation emission matrix spectroscopy. Mar Chem 51:325-346

Del Castillo CE, Gilbes F, Coble PG, Muller-Karger FE (2000) On the dispersal of riverine colored dissolved organic matter over the West Florida Shelf. Limnol Oceanogr 45: 1425-1432

Del Vecchio R, Blough NV (2002) Photobleaching of chromophoric dissolved organic matter in natural waters: kinetics and modeling. Mar Chem 78:231-253

Detres Y, Armstrong RA, Connelly XM (2001) Ultravioletinduced responses in 2 species of climax tropical marine macrophytes. J Photochem Photobiol B Biol 62:55-66

Duarte CM (1999) Seagrass ecology at the turn of the millenium: challenges for the new century. Aquat Bot 65:7-20

Durako MJ, Kunzelman JI, Kenworthy WJ, Hammerstrom KK (2003) Depth-related variability in the photobiology of two populations of Halophila johnsonii and Halophila decipiens. Mar Biol 142:1219-1228

Figueroa FL, Jimenez C, Vinegla B, Perez-Rodriguez E and 5 others (2002) Effects of solar UV radiation on photosynthesis of the marine angiosperm Posidonia oceanica from southern Spain. Mar Ecol Prog Ser 230:59-70

Fourqurean JW, Willsie AW, Rose CD, Rutten LM (2001) Spatial 
and temporal pattern in seagrass community composition and productivity in south Florida. Mar Biol 138:341-354

Frederick JE, Lubin D (1988) The budget of biologically active ultraviolet radiation in the earth-atmosphere system. J Geophys Res 93D 93:3825-3832

Gao H, Zepp RG (1998) Factors influencing photoreactions of dissolved organic matter in a coastal river of the southeastern United States. Environ Sci Technol 32:2940-2946

Green SA, Blough NV (1994) Optical absorption and fluorescence properties of chromophoric dissolved organic matter in natural waters. Limnol Oceanogr 39:1903-1916

Grzybowski W (2000) Effect of short-term sunlight irradiation on absorbance spectra of chromophoric organic matter dissolved in coastal and riverine water. Chemosphere 40: 1313-1318

Haeder DP, Kumar HD, Smith RC, Worrest RC (2003) Aquatic ecosystems: effects of solar ultraviolet radiation and interactions with other climate change factors. Photochem Photobiol Sci 2:39-50

Harrison PG (1989) Detrital processing in seagrass systems: a review of factors affecting decay rates, remineralization, and detritivory. Aquat Bot 23:263-288

Hemminga M, Duarte CM (2000) Seagrass ecology. Cambridge University Press, Cambridge

Hernandez ME, Mead R, Peralba MC, Jaffe R (2001) Origin and transport of $n$-alkane-2-ones in a subtropical estuary: potential biomarkers for seagrass-derived organic matter. Org Geochem 32:21-32

Hoge FE, Vodacek A, Swift RN, Yungel JK, Blough NV (1995) Inherent optical properties of the ocean-retrieval of the absorption coefficient of chromophoric dissolved organic matter from airborne laser spectral fluorescence measurements. Appl Optics 34:7032-7038

Hu CM, Muller-Karger FE, Zepp RG (2002) Absorbance, absorption coefficient, and apparent quantum yield: a comment on common ambiguity in the use of these optical concepts. Limnol Oceanogr 47:1261-1267

Jaffé R, Boyer JN, Lu X, Maie N, Yang C, Scully NM, Mock S (2004) Source characterization of dissolved organic matter in a mangrove dominated estuary by fluorescence analysis. Mar Chem 84:195-210

Kieber DJ, Peake BM, Scully NM (2003) Reactive oxygen species in aquatic ecosystems. In: Zagarese HE (ed) UV effects in aquatic organisms and ecosystems. The Royal Society of Chemistry, Cambridge, p 251-288

Larkum A, Wood WF (1993) The effect of UV-B radiation on photosynthesis and respiration of phytoplankton, benthic macroalgae and seagrasses. Photosynth Res 36:17-23

Lesser MP (2000) Depth-dependent photoacclimatization to solar ultraviolet radiation in the Caribbean coral Montastraea faveoloata. Mar Ecol Prog Ser 192:137-151

Markager S, Vincent WF (2000) Spectral light attenuation and the absorption of UV and blue light in natural waters. Limnol Oceanogr 45:642-650

McKnight DM, Boyer EW, Westerhoff PK, Doran PT, Kulbe T, Andersen DT (2000) Spectrofluorometric characterization of dissolved organic matter for indicator of precursor organic material and aromaticity. Limnol Oceanogr 46:34-48

Miller WL (1998) Effects of UV radiation on aquatic humus: photochemical principles and experimental considerations. In: Hessen T (ed) Aquatic humic substances. SpringerVerlag, Berlin, p 125-143

Miller WL, Moran MA, Sheldon WM, Zepp RG, Opsahl S (2002) Determination of apparent quantum yield spectra for the formation of biologically labile photoproducts. Limnol Oceanogr 47:343-352

Mopper K, Kieber DJ (2000) Marine photochemistry and its impact on carbon cycling. In: Vernet M (ed) The effects of UV radiation in the marine environment. Cambridge University Press, Cambridge, p 101-129

Moran MA, Zepp RG (1997) Role of photoreactions in the formation of biologically labile compounds from dissolved organic matter. Limnol Oceanogr 42:1307-1316

Moran MA, Sheldon WM, Zepp RG (2000) Carbon loss and optical property changes during long-term photochemical and biological degradation of estuarine dissolved organic matter. Limnol Oceanogr 45:1254-1264

Nelson NB, Siegel DA, Michaels AF (1998) Seasonal dynamics of colored dissolved material in the Sargasso Sea. Deep-Sea Res Part I 45:931-957

Odum EP (1971) Fundamentals of ecology. WB Saunders Company, Philadelphia, PA

Opsahl S, Benner R (1993) Decomposition of senescent blades of the seagrass Halodule wrightii in a subtropical lagoon. Mar Ecol Prog Ser 94:191-205

Osburn CL, Morris DP (2003) Photochemistry of chromophoric dissolved organic matter in natural waters. In: Helbling EW, Zagarese H (eds) UV effects in aquatic organisms and ecosystems, Vol 1. The Royal Society of Chemistry, Cambridge, p 185-217

Osburn CL, Zagarese HE, Morris DP, Hargreaves BR, Cravero W (2001) Calculation of spectral weighting functions for the solar photobleaching of chromophoric dissoved organic matter in temperate lakes. Limnol Oceanogr 46:1455-1467

Peterson BJ, Fourqurean JW (2001) Large-scale patterns in seagrass (Thalassia testudinum) demographics in south Florida. Limnol Oceanogr 46:1077-1090

Rice DL, Tenore KR (1981) Dynamics of carbon and nitrogen during the decomposition of detritus derived from estuarine macrophytes. Estuar Coast Shelf Sci 13:681-690

Sierra MMD, Donard OFX, Lamotte M, Belin C, Ewald M (1994) Fluorescence spectroscopy of coastal and marine waters. Mar Chem 47:127-144

Stabenau ER, Zika RG (2004) Correlation of the absorption coefficient with a reduction in mean mass for dissolved organic matter in Southwest Florida river plumes. Mar Chem 89:55-67

Stedmon CA, Markager S (2001) The optics of chromophoric dissolved organic matter (CDOM) in the Greenland Sea: an algorithm for differentiation between marine and terrestrially derived organic matter. Limnol Oceanogr 46: 2087-2093

Stumpf RP, Frayer ML, Durako MJ, Brock JC (1999) Variations in water clarity and bottom albedo in Florida Bay from 1985 to 1997. Estuaries 22:431-444

Twardowski MS, Donaghay PL (2001) Separating in situ and terrigenous sources of absorption by dissolved materials in coastal waters. J Geophys Res-Oceans 106:2545-2560

Vähätalo AV, Wetzel RG (2004) Photochemical and microbial decomposition of chromophoric dissolved organic matter during long (months-years) exposures. Mar Chem 89: 313-326

Vähätalo AV, Salonen K, Saski E, Salkinoja-Salonen M (2002) Bleaching of color of kraft paper mill effluents and natural organic matter in lakes. Can J Fish Aquat Sci 59:808-818

Vodacek A, Blough NV, DeGrandpre MD, Peltzer ET, Nelson RK (1997) Seasonal variation of CDOM and DOC in the Middle Atlantic Bight: terrestrial inputs and photooxidation. Limnol Oceanogr 42:674-686

Whitehead RF, de Mora S, Demers S, Gosselin M, Monfort P, Mostajir B (2000) Interactions of ultraviolet-B radiation, mixing, and biological activity on photobleaching of natural chromophoric dissolved organic matter: a mesocosm study. Limnol Oceanogr 45:278-291 
Zanardi-Lamardo E, Clark CD, Moore CA, Zika RG (2002) Comparison of the molecular mass and optical properties of colored dissolved organic material in two rivers and coastal waters by flow field-flow fractionation. Environ Sci Technol 36:2806-2814

Zepp RG (2003a) Solar ultraviolet radiation and aquatic biogeochemical cycles. In: Helbling EW, Zagarese H (eds) UV effects in aquatic organisms and ecosystems, Vol 1. The Royal Society of Chemistry, Cambridge, p 137-184

Zepp RG (2003b) UV exposure of coral assemblages in the Florida Keys. Report No. EPA/600/R-03/095, US Environmental Protection Agency, Athens, GA

Zepp RG, Callaghan TV, Erickson DJ (2003a) Interactive effects of ozone depletion and climate change on biogeochemical cycles. Photochem Photobiol Sci 2:51-61

Zepp RG, Moran MA, Koopmans D (2003b) Photoreactivity of chromophoric dissolved organic matter (CDOM) derived from decomposition of various vascular plant and algal sources. Preprint Extended Abstract, Environmental Chemistry Division, 225th American Chemical Society National Meeting, New Orleans, LA

Zepp RG, Moran MA, Stabenau E, White EM (2002) Photochemical and biological degradation of CDOM in waters

Editorial responsibility: Otto Kinne (Editor),

Oldendorf/Luhe, Germany from selected coastal regions of the southeastern United States. EOS Trans AGU 83:OS278. American Geophysical Union. Washington, DC

Zepp RG, Sheldon WM, Moran MA (2004) Dissolved organic fluorophores in southeastern U.S. coastal waters: correction method for eliminating Rayleigh and Raman scattering peaks in excitation-emission matrices. Mar Chem 89:15-36

Ziegler S, Benner R (1998) Ecosystem metabolism in a subtropical, seagrass-dominated lagoon. Mar Ecol Prog Ser 173:1-12

Ziegler S, Benner R (1999a) Dissolved organic carbon cycling in a subtropical seagrass-dominated lagoon. Mar Ecol Prog Ser 180:149-160

Ziegler S, Benner R (1999b) Nutrient cycling in the water column of a subtropical seagrass meadow. Mar Ecol Prog Ser 188:51-62

Ziegler S, Benner R (2000) Effects of solar radiation on dissolved organic matter cycling in a subtropical seagrass meadow. Limnol Oceanogr 45:257-266

Zieman JC, Fourqurean JW, Iverson RL (1989) Distribution, abundance and productivity of seagrasses and macroalgae in Florida Bay. Bull Mar Sci 44:292-311

Submitted: January 9, 2004; Accepted: June 22, 2004

Proofs received from author(s): October 29, 2004 